\title{
Comparative historical political economy
}

\author{
PETER J. BOETTKE ${ }^{\dagger}$ \\ George Mason University, USA \\ CHRISTOPHER J. COYNE \\ George Mason University, USA \\ PETER T. LEESON ${ }^{\S}$ \\ George Mason University, USA
}

\begin{abstract}
Investigations of a society's competitiveness aim to trace the causal mechanisms behind patterns in wealth and poverty across societies. This paper argues that to be productive such investigations must be comparative, historical and political economic in nature. Comparative historical political economy is how social scientists generate useful knowledge about the wealth and poverty of nations. Our contribution is a methodology —or rather a collection of methodologies-for understanding national competitiveness and attempts to improve it: one focuses on political-economic analysis, another on historical analysis, and a third on comparative analysis.
\end{abstract}

\section{Introduction}

The study of national competitiveness was born in an exercise in comparative historical political economy. In 1776 Adam famously asked: Why are some nations rich and others poor? Smith's answer was that increased productive capabilities-the result of an expanding division of labor and exchange-create improvements in man's material conditions. Some nations historically developed institutional environments-namely those rooted in private property rights - that facilitate productivity increases by incentivizing specialization and exchange. These nations are wealthy. Others nations historically developed institutional environments that neglect private property rights. Their institutional environments retard productivity by undermining specialization and exchange. These nations are poor.

Smith summarized the central lesson from his comparative, historical, political-economic analysis as follows: "Little else is requisite to carry a state to the highest degree of opulence from the lowest barbarism but peace, easy taxes and a tolerable administration of justice."

† Email: PBoettke@GMU.edu. Address: George Mason University, Department of Economics, MS 3G4, Fairfax, VA 22030.

‡Email: CCoyne3@GMU.edu. Address: George Mason University, Department of Economics, MS 3G4, Fairfax, VA 22030.

§ Email: PLeeson@GMU.edu. Address: George Mason University, Department of Economics, MS 3G4, Fairfax, VA 22030.

The authors thank the F.A. Hayek Program for Advanced Study in Philosophy, Politics, and Economics at the Mercatus Center at George Mason University for supporting this research. 
(1976: xliii). The same question that motivated Smith in the $18^{\text {th }}$ century motivates social scientists at the turn of the $21^{\text {st }}$. Since the mid-1980s scholars from the most technical (e.g., Robert Lucas) to the most popular (e.g., Jared Diamond) have been preoccupied with the differences in economic development across countries. The continued preoccupation with Smith's question doesn't reflect an error in Smith's basic answer. It reflects the need for much unpacking of that answer-both to understand the nuances of the causes and consequences of national competitiveness and to understand how, if at all, Smith's lesson might be applied to the plight of underdeveloped countries in practice.

This paper begins with the assumption that the purpose of contemporary investigations into national competitiveness is to trace the causal mechanisms behind patterns in wealth and poverty across societies. We argue that to be productive, investigations into national competiveness must be historical, comparative, and political economic in nature. Comparative historical political economy is how social scientists generate useful knowledge about the wealth and poverty of nations. Rather than containing original arguments or results, this paper serves as a survey of some existing developments in the literature and provides a synthesis and prospectus for future research.

Our paper is connected to several literatures. The first considers institutions and economic performance (see, for instance, Hodgson 1988, 1993, 1999 and forthcoming; North 1990, 2005; Ostrom 1990, 2005; Besley and Persson, 2011; Acemoglu, Johnson, and Robinson 2001, 2002; Acemoglu and Robinson, 2012; Boettke, Coyne, Leeson and Sautet, 2005; Boettke, Coyne, and Leeson, 2008). This literature tells us "institutions matter." But it says much less about how institutions matter in the particular contexts in which they develop. Our discussion suggests a way of evaluating how institutions matter in the particular contexts in which they develop for national competiveness.

Our paper is also connected to the literature on institutional and policy reform (see, for instance, Ostrom, et al., 2001; Rodrik, 2007; World Bank, 2008). This research focuses on diagnosing the highest value reforms measured by economic growth. The method of comparative historical political economy we present provides a way of identifying what reforms aimed at increasing national competitiveness are feasible, which necessarily precedes selecting the highest-valued reform.

Finally, our paper contributes to the literature on robust political economy (see, for instance, Boettke and Leeson, 2004; Leeson and Subrick, 2006). That literature emphasizes the fact that effective political and economic institutions must cope with human ignorance while simultaneously guarding against opportunism. However, robust political-economic institutions vary from one context to the next. Our analysis suggests a means of identifying what these institutions of national competitiveness are in a particular case. As a matter of methodological principle, in our explorations of positive cases of the evolution of social cooperation we argue that the more unfavorable the initial conditions are for cooperation the stronger the case will be for identifying mechanisms that permit cooperation to emerge, and in the negative cases of the devolution of social cooperation under alternative institutional arrangements we argue that the more favorable the initial conditions are for cooperation the stronger the case will be for identifying the mechanism flaws that result in cooperation failing to emerge. There are other reasons to resurrect the defense of small-N case studies in political economy as argued by Bates, et. al., (1998), but for the sort of comparative political economy analysis we are surveying case selection is all important, and the generalizability of the results are more reliable the more we guard against "cherry picking" the cases to fit with our 
theoretical priors. Thus, the explicit effort to focus on cases where the initial conditions that represent an acute challenge to those priors.

Each of the following three sections addresses a question posed by our hypothesis that productive investigations into national competitiveness must be historical, comparative and political economic. Section 2 addresses why political economy is necessary for investigations into national competitiveness to be productive. We trace the origins and development of political economics and argue for its importance for understanding the causal mechanisms that drive the wealth or poverty of nations. Section 3 addresses why historical analysis is necessary for productive inquiries into national competitiveness. We explain why and how history matters for the status quo and how the status quo serves as a constraint on reforms associated with moving from poverty to wealth. Section 4 addresses why comparative analysis is necessary to generate knowledge about national competitiveness. We argue that only by comparing relevant institutional and policy alternatives can social scientists and policymakers glean valid insights for appraising a nations' success or failure in creating wealth and considering how to improve impoverished nations' capacity to prosper. Section 5 concludes.

\section{Why Political Economy?}

In its early days "political economy" referred to social science in the mode of its pioneer, Adam Smith. That mode of social science included an appreciation and incorporation of history, politics, and the law, in addition to economic theory. That mode was also normative. It was intimately connected to moral philosophy.

At the turn of the $20^{\text {th }}$ century an intellectual revolution occurred in economics: political economy began to transform into the science of economics. This terminological change was meant to reflect a maturing of the discipline - a signal of its development from humble beginnings as a branch of moral philosophy to a positive science. Critical in this switch was the importation of concepts and techniques from physics into political economy to restructure the discipline into economics. ${ }^{1}$ Purging the remnants of the discipline's interdisciplinary heritage took half a century. The "purified" product was Paul Samuelson's (1947) Foundations of Economic Analysis.

Several economists expressed concerns about Samuelson's agenda and purified economics' implications for policy (see, for instance, Boulding, 1948). But most found the idea of an institutionally antiseptic economic discipline attractive. Thus the new approach captured the imagination of most economists coming of professional age after the Great Depression and WWII. This generation of economists focused on using Samuelson's economic toolkit to correct market failures and actively manage the economy through expert control.

A good example of this is Abba Lerner (1944) who titled his famous book The Economics of Control. However, as Milton Friedman (1947) pointed out in his review of Lerner's work, that book, which spent its pages focusing on the formal conditions for an optimum, neglected institutions and context. It expressed economics as if economic decision making occurred in vacuum. Thus it couldn't appraise the administrative problems of the policies Lerner proposed or their social and political ramifications.

Until the 1980s the term "political economy” remained reserved for heterodox economists. Not until then had the growing counter-revolution in law and economics, property rights

1 For a history of this intellectual evolution see Mirowski (1991). 
economics, public choice economics, new economic history, and the new institutional economics developed sufficiently that an economics that put institutions center stage-and did so through positive rather than normative analysis-was again recognizable as a viable research program in a discipline now called economic science. ${ }^{2}$ Today this "new" political economy has regained its footing.

New political economy (which hereafter we simply call "political economy") seeks to understand individuals' economic activities through an approach that gives weight to the political and legal environment those activities take place in and to the beliefs those individuals hold in their particular contexts (see Boettke and Storr, 2002). In this view economic behavior, economic organizations, and economic policy never exist in a vacuum but always within a broader social context.

Vernon Smith (2003) calls this context "ecology" and contrasts "ecological rationality" with "constructivist rationality" in economic analysis. Ecological rationality respects the context of choice. We may think of ecological rationality as a central starting place of studies in political economy. In contrast, constructivist rationality attempts to judge choice independent of context. We may think of constructivist rationally as a central starting place in what above we called institutionally antiseptic economics in the vein of Samuelson and Lerner. The problem with the constructivist rationality approach institutionally antiseptic economics takes is that this approach misses the central source of variation in human behavior and thus the central source of the variation in national competitiveness. ${ }^{3}$

Social scientists generate knowledge about national competitiveness by engaging in a thought experiment that plays on the interaction between an analysis of the effectiveness of various means to obtain desired ends and philosophical speculation over what ends society should pursue. In practice society must instantiate desired ends through institutions. Those institutions structure the incentives individuals face and control the flow and quality of information that individuals process in making choices. The way individuals pursue their purposes (i.e., the arranging of means to obtain ends) is a function of the incentives they face and the information they have to work with. Thus alternative institutional arrangements steer human behavior in alternative directions.

Economics constrains social philosophy by highlighting the strategies that individuals are likely to pursue - the behaviors they're likely to engage in-under alternative institutional arrangements. In the intellectual exercise of tacking back and forth between the instrumental rationality of means-ends analysis and the social-philosophic quest for "good rules of life"i.e., political-economic inquiry-knowledge about national competitiveness emerges. But that

2 This collection of research programs often goes under the names public choice, rational choice politics, modern political economy, Virginia School of Political Economy, Chicago School of Political Economy, the theory of collective action, positive political economy, Constitutional Political Economy, New Institutional Economics, and more recently political economics. There are subtle (and sometimes profound) differences in these different approaches. But for our purposes what matters is that each of these movements sought to incorporate into the basic model of social interaction the political-legal-social dimension whereas before the dominant intellectual move was to treat these factors as external to the model.

3 Once one takes this intellectual step, we believe, then many of the old dichotomies between atomistic individualism and wholism, and between universal theory and institutional specifics, fade away. Mainline political economy works with an institutional individualism, and blends the argumentative structure of theory with the institutional specifics of history. Among contemporary social scientists Elinor Ostrom's work is perhaps most suggestive as to how the old dichotomies are not as accurate or as intellectual fruitful as once believed. On the intellectual lineage of mainline political economy see Boettke 2012. 
knowledge can't emerge if the social scientist is prevented from engaging such tacking back and forth because there's no institutionally dependent behavior to tack back to.

Thus, in contrast to political economy, institutionally antiseptic economics has no means of analyzing national competitiveness. There's constrained maximization. But institutions don't exist to shape those constraints. It's unclear, then, where the significant source of variation in individuals' behavior that could lead to variations in national competitiveness-variations in countries' wealth and poverty-could come from.

Perhaps endowment differences-differences in geography and natural resources (though even the latter is endogenous to institutions)_-across countries could be invoked as a source of variation in national competitiveness. The problem here is that recent scholarship shows us quite clearly that institutional variation, not variation in geography or resources, drives observed differences in countries' wealth and poverty.

Acemoglu, Johnson, and Robinson's (2001, 2002) work on the "Colonial Origins of Comparative Development" is perhaps the best of example of this research. That work examines the institutional legacies_- "good" and "bad" - that European colonists left in their former colonies. Acemoglu, Johnson, and Robinson argue that varying disease climates across the colonies had a major influence on the institutional arrangements colonizers established in those places. Where the disease environment was inhospitable to long-term settlement, colonists set up "extractive institutions" that facilitated their ability to quickly exploit the indigenous population and its resources. Where the disease environment was more hospitable, colonists stuck around. Here their incentive was to set up institutions of long-term prosperity, namely those that created widespread private property rights.

Since institutions change slowly, colonies that inherited extractive institutions continue under those institutions today, making them poor. On the other hand, colonies that inherited private property rights institutions continue to enjoy those that institutional regime today, making them rich. When institutional variation is accounted for, Acemoglu, Johnson, and Robinson find that former colonies’ geography has no direct effect on their income.

Acemoglu, Johnson, and Robinson's political-economic analysis has contributed greatly to our understanding of national competitiveness. It has done so by focusing attention on the historical and institutional conditions affecting wealth and poverty across countries. ${ }^{4}$ The empirical tools this research uses to address national competitiveness differ from the tools the classical political economists used for this purpose. But these researchers' political-economic approach-one that makes institutional context central, rather than incidental, to illuminating the question of national competitiveness-has its origins in the approach to that question that goes back to Adam Smith. We can think of no example of an institutionally antiseptic economics-approach that has contributed to our knowledge about national competitiveness comparable to that which the political-economic approach provides.

James Buchanan (1975) uses the language of pre- and post-constitutional levels of analysis to communicate the idea that the interaction between economics and social philosophy produces political economy. In his framework the pre-constitutional level of human decision making focuses on a choice over rules of the game and involves a debate about what kind of rules produce a "good game." The post-constitutional level of human decision making focuses

4 Acemoglu and Robinson (2012) have developed their argument further in Why Nations Fail, and focus on the character of the institutions adopted in terms of "extraction of resources" and "inclusiveness in the political process”. For a political-economic analysis of development also see Besley and Persson (2011). 
on understanding what strategies individuals will pursue to fulfill their plans given the rules they agree to at the pre-constitutional level.

Buchanan points out that if the rules of the game are desirable at a philosophical level but result in strategies that undermine social progress, our social philosophy is wrong-headed. The meta-question "What rules make for a good game?" can't be answered without a rationalchoice analysis of the strategies individuals will follow under a game defined by those rules. Social scientists interested in addressing national competitiveness must constantly ask about the practical problems associated with how individuals will play the game under certain rules. Will those rules encourage mutually beneficial interactions or discourage them? Will they promote opportunism or discourage it? Inefficiency and opportunism impose real-world constraints on the philosophic daydreaming of social reformers.

Another useful distinction that Buchanan (1975) makes that we argue must be incorporated into any political-economic analysis is between the protective state (law and order), productive state (public goods), and redistributive state (rent-seeking state). And the puzzle that must be examined is whether political/legal institutions can be established which produce the protective and productive state without unleashing the redistributive state to such an extent that it undermines the wealth generating capacity of the society.

Political-economic analysis generates useful knowledge about national competitiveness by carefully separating positive and normative levels of analysis. Political economy so conceived is a tool of interpretation and social criticism. But it's not a tool of policy advocacy. Policy advocacy requires moral theorizing. It requires the advocate to explicitly state his moral stance and to defend that stance against alternatives. In contrast, social criticism can be immanent rather than transcendent: this is the role of political-economic analysis. Political economy puts parameters on people's utopias. In this view political economy provides an interpretative framework for the student of society rather than an action plan for society's would-be saviors.

This distinction is important since the presumptive benefit of institutionally antiseptic economics is that it ensures a cleaner division of positive and normative claims. If political economy is seen as a way to put parameters on the utopias selected by others, however, that presumptive benefit withers. Institutionally antiseptic economics permits neither an investigation of national competitiveness (owing to its inability to examine institutional arrangements) nor does it do more to prevent us from importing normative judgments into our analysis. In contrast, political economy conceived along the lines described above both restricts itself to positive analysis by performing means-ends evaluations of externally supplied ends and enables the generation of useful knowledge about national competitiveness by putting the central source of variation in that competitiveness-institutions-at the center of its study.

\section{Why Historical?}

An economy's competitiveness depends on institutions that define its "rules of the game." Economists since Adam Smith have been aware of the "first-order" institutions of prosperitythose that support private property rights. But moving toward such institutions is easier said than done. One important reason for this is that potential movements in this direction always occur from an institutional status quo that constrains what movements are possible. For example, vested interests under the existing institutional regime may preclude reforms that would make an economic system more competitive. Effective institutions of economic governance are nested within each other. Closely related, the historical factors that led to 
existing institutions and created existing stakeholders may make it harder, or even impossible, for institutions to move in the short run. Historical specificity is an essential starting point of any political economy analysis of institutional reform as it defines the existing status quo rather than some imaginary starting point for political economic analysis. ${ }^{5}$

The literature that focuses on the idea of institutional path dependence recognizes history's importance for institutions (see, for instance, North, 1990; Pierson 2000a, 2000b; Buchanan and Yoon, 1994). This work emphasizes that increasing returns can "lock in" particular institutional arrangements that emerged for particular historical reasons. Institutional lock-in matters because historical institutional arrangements may be suboptimal from the perspective of the situation most individuals governed by those institutions find themselves in today. Rules and enforcement technologies that contributed to wealth creation centuries ago may no longer do so in the present. Citizens would be better off if they moved to other institutional arrangements, as in the case of uncompetitive economies.

When path dependence locks institutional arrangements in, citizens can't to move to a superior institutional path without an exogenous shock. This has led members of the international development community to emphasize the importance of providing such shocks to underdeveloped economies to catalyze institutional reform. Development community supplied shocks include activities such as nation building and various forms of foreign assistance for uncompetitive economies, for instance to strengthen judicial institutions or to promote democratic political institutions in poor countries.

The effectiveness of these efforts to generate institutional improvement has been mixed at best. Foreign aid has failed to deliver on its promise to end poverty (Easterly 2001, 2006; Williamson, 2010; Coyne, 2013). And efforts to export democracy through military occupation have led to more failures than successes (Coyne, 2008). Elsewhere we've argued that these failures result largely from a failure to appreciate how history matters for national competitiveness in underdeveloped nations (Boettke, Coyne and Leeson, 2008). The literature on institutional path dependence highlights that history is important in explaining existing institutional conditions. But it says little about the specifics of how history matters for institutional conditions.

Boettke, Coyne, and Leeson (2008) argue that "institutional stickiness" - the ability (or inability) of proposed institutional arrangements to take-hold where they're transplanted-is critical to understanding how history matters for institutions in particular nations and hence their economies' competitiveness. Institutional stickiness depends on how well formal institutions, such as political institutions to support property rights, map onto informal ones, such as citizens' norms and beliefs (see also, Denzau and North, 1994; North, 2005; Boettke, 2002). ${ }^{6}$ The stickiest institutions are those that developed "organically" through historical processes: the informal institutions pointed to above. Indeed, norms and beliefs may be

5 There is also the methodological challenge that acknowledging historical specificity raises to the social sciences. As Hodgson $(2001,23)$ points out, that "there are different types of socio-economic system, in historical time and geographic space. The problem of historical specificity addresses the limits of explanatory unification in social science: substantially different socio-economic phenomena may require theories that are in some respects different." But as Hodgson argues in How Economics Forgot History, there are various ways to blend theory and conceptual clarity with historical specificity, and in fact this blending of theory/history is perhaps the strongest common-bond in the literature we are surveying as it steers between ahistorical formalistic theory (formalism) and unaided fact gathering and historical documentation (historicism).

6 Coyne and Leeson (2009) discuss mass media's role in shaping informal institutions, such as norms, and formal ones, such as political institutions. 
usefully thought of as "institutionalized history." The least sticky institutions are those without such historical roots-those that lack "historical memory." These institutional arrangements have no precedence among the people they're intended to govern.

Where formal institutions align closely with the informal ones, the former tend to function as desired since enforcement costs are comparatively low. Citizens' behaviors comport with state-supported rules without excessive prodding. In contrast, where informal institutional arrangements deviate significantly from formal ones, the former will conflict with the latter, making enforcement very expensive. That expense undermines an economy's competitiveness. This reasoning suggests that discussions about institutional reform to foster national competitiveness must first understand the informal institutions - and thus the histories - that give, or don't give, proposed reforms the stickiness required to function effectively where reformers seek to establish them. Analyses that ignore history ignore a key constraint on what institutional arrangements are possible across societies.

Economic theory provides social scientists with a pair of "analytical eyeglasses" they must use to "read" empirical world and construct compelling narratives about the relationship between underlying informal institutional arrangements - the products of historical processes_and the proposed formal institutional reforms that might improve an economy's competitiveness. Those eyeglasses permit social scientists to engage in political-economic analysis along the lines described above.

This narrative form of reasoning has made a comeback in political economy over the last decade with the work of Robert Bates, Avner Greif, and Barry Weingast (1998) in what they call the "analytic narrative" approach to political economy. Their approach combines rational choice theory with a narrative-style of exposition to simultaneously fill out institutional details required to understand how history matters in a particular case-the "stickiness" we describe above-and constrains that understanding by requiring it to conform to the strictures of economic logic — the parameterization of utopias pointed to earlier.

The analytic narrative approach to political economy is increasingly looked on as a productive method to explore questions of political economy. Examples of such work include Greif (2006), Djankov et al. (2003), and Leeson (2007a, 2007b, 2008, 2009a, 2009b). The analytic method approach offers a fruitful path for understanding feasible reforms aimed at increasing competitiveness by facilitating a comparative analysis of alternative institutional arrangements, something we focus on below. This is crucial since, as Rodrik (2007: 15) points out, while competitiveness-enhancing institutions have the same function across economiesnamely, the protection of private property-their form is context, and thus historically, dependent. ${ }^{7}$

\section{Why Comparative?}

7 The distinction between form and function is also important in Elinor Ostrom's various studies of the management of common-pool resources. The long enduring institutional practices that she has identified across cultures and time come in diverse forms, but they all function by limiting access, assigning responsibility and introducing graduated penalties for violators of the social rules. This distinction in the operation of rules is important for understanding how historical specificity operates on the institutional configurations in place, and how these in turn shape economic decisions by the relevant actors. There is also the important distinction between rule in form, and rules in use. And again what matters for economic analysis of alternative institutional arrangements is the rules in use (including informal rules, as well as understanding rule violations due to lack of enforcement). 
To generate useful knowledge about national competitiveness social scientists must compare alternative institutional arrangements-how alternative institutions affect the flow and quality of information that individuals have at their disposal when making choices and influence individuals' incentives to behave. Equally important, they must compare relevant alternatives. We learn nothing of practical usefulness for national competitiveness by comparisons of the status quo with institutional alternatives that are outside the reach of the economies under examination.

Understanding competitiveness is therefore a matter of comparing feasible institutional alternatives: these are the relevant ones. As we indicated above, institutional arrangements' feasibility depends on the status quo. Ignoring the importance of history and the status quo it has created results in a faulty comparative institutional analysis. What appear to be institutional alternatives in principle may not be institutional alternatives in practice. History constrains the institutional possibility set. It makes some institutional regimes unfeasible. Thus when social scientists discuss empirical phenomena in political economy, they must always ask the question “As compared to what?” (Boettke 1990, 1993, 2002).

Consider a familiar example. The workplace conditions of British laborers during the Industrial Revolution were miserable compared to those enjoyed by laborers post-WWII. This comparison is sometimes drawn by those who want to show that the growth of capitalism in the UK impinged laborers' welfare. They may be right (though we highly doubt it). But this comparison is the wrong one to make to evaluate the matter. It's nonsensical to compare Industrial Revolution-era laborers' work conditions to post WWII-era laborers' work conditions for this purpose. Employers in the two eras confronted different constraints, which made the cost and possibility of better workplace conditions different in the two eras as well. Post-WWII workplace conditions weren't available to Industrial Revolution-era laborers. It's unreasonable then to use this as the comparative benchmark against which to judge how the Industrial Revolution affected laborers' welfare. The relevant comparison is what Industrial Revolution-era workplace conditions were like relative to the feasible alternatives, namely the workplace conditions in the countryside from which factory workers were drawn. This comparison leads to a very different conclusion from the one the Industrial Revolution critics want to draw. The critical piece is getting the benchmark right-making the relevant comparison instead of the irrelevant one.

Despite the obviousness of this point, a surprising number of discussions in political economy proceed along lines similar to those adopted by the Industrial Revolution critics above. The context is different. But the faulty comparison and thus wrongheaded conclusions about national competitiveness are the same.

Consider the case of sweatshops. Although many economists avoid this confusion, policymakers are much more prone to use irrelevant comparisons to draw political-economic conclusions. A common refrain from sweatshop critics is that by paying low wages, sweatshops hinder laborers' ability to build wealth in developing countries. To level this criticism they compare sweatshop wages to wages in developed countries from which the critics inevitably come. But those wages are an irrelevant point of comparison. Laborers in developing countries have less human capital and physical capital to work with. The high wages enjoyed by American laborers who work with more capital are therefore unavailable to them. The relevant comparison for sweatshop wages is how those wages fare relative to wages in non-sweatshop employments in developing countries. These are sweatshop laborers' relevant alternatives. 
Powell and Skarbek (2006) perform such a comparison for sweatshop wages in developing countries. They find that sweatshops pay above average wages in most developing countries and thus enhance rather than reduce sweatshop employees' material welfare. Useful knowledge about sweatshop laborers' material welfare requires a comparison to the relevant alternative, not the irrelevant one.

Similarly, Hall and Leeson (2007) engage in a comparative analysis that examines the "income threshold" today's highly developed countries surpassed at the time they found it affordable to introduce more stringent labor market regulations, such as prohibitions on child labor, the minimum wage, and mandatory workplace safety requirements. Despite calls from some international organizations to introduce these standards in developing countries, such as those in Sub-Saharan Africa, Hall and Leeson find that virtually no developing country in that region has achieved a level of wealth sufficient to safely trade off additional income for additional labor regulation. Their study highlights that the relevant comparison when considering the adoption of more stringent labor standards in Sub-Saharan Africa isn't the state of those standards in developed countries. It's the state of those standards in developed countries when there were at a comparable level of underdevelopment.

Comparing relevant alternatives is especially important when engaging in politicaleconomic analyses of "weak" and "failed" states. Coyne (2006), Leeson (2007c), Leeson and Williamson (2009), and Powell, Ford, and Nowrasteh (2008) use comparative analysis to confront the widely-held belief that anarchic Somalia is a land of chaos and that Somalis have suffered from the collapse of government in 1991. These authors highlight that the relevant comparison for Somali development under anarchy isn't development in North America or Western Europe under highly functional and effective government unless a North American- or Western European-style government is a genuine institutional option for Somalia, which Somalia's history would suggest it isn't. Instead, the relevant comparison is Somali development under the highly corrupt and dysfunctional government Somalis lived under before anarchy - the kind of government we could expect Somalis to live under again if history is any indicator about the kind of government that's like to take hold there. This is Somalia's relevant institutional alternative to anarchy. Compared to this alternative, Somali development has improved under anarchy on nearly all available indicators. This leads to a rather different conclusion about how to evaluate institutional arrangements in Somalia and what to do with respect to those institutions going forward, if anything, than that which the common hand wringing about statelessness in Somalia would suggest.

The studies discussed above underscore the sensitivity of conclusions about national competitiveness to the political economist's benchmark and thus the necessity of getting the relevant institutional alternative right when conducting political-economic analyses. Without the relevant comparison, social scientists can't generate useful knowledge about national competitiveness.

Just as it's unhelpful to compare the status quo with alternatives that are outside the opportunity set, it's unhelpful to compare the empirical reality of one political economic system with the theoretical claims of an alternative political economic system. For example, using the theoretical assumptions of socialism in which man's nature is transformed such that he never behaves opportunistically, one could easily conclude by looking at "real-world capitalism" that socialism is a superior political-economic arrangement. But this conclusion wouldn't be valid because the comparison wouldn't be valid. The empirical reality of any political-economic arrangement will fall short of the idealized theoretical outcomes of any 
other political economic arrangement by construction. ${ }^{8}$ Theory must be compared with theory and empirical reality with empirical reality.

This point is elementary. Yet it goes unheeded in much policy. For example, Coyne (2006, 2008) explores how foreign occupiers' interventions in weak and failed states suffer from a "nirvana fallacy" that commits precisely this error. Foreign occupiers compare the potential outcomes of these interventions - their idealized outcomes-with the imperfect reality that confront instead of comparing how the real-world manifestation of those interventions are likely to fare next to the status quo. This often leads to interventions that put weak and failed states in a worse position than they were before occupation.

Of special interest for evaluating national competitiveness when comparing relevant institutional alternatives is evaluating those alternatives" "robustness" or "fragility." Robustness here refers institutions' ability to cope with ignorance and guard against our opportunism while cultivating an economic environment that permits individuals to pursue their plans freely, to bet on their entrepreneurial ideas, and to find the financing to bring those economic ideas to life in the marketplace (Boettke and Leeson, 2004; Leeson and Subrick, 2006).

In contrast, one can imagine institutional arrangements that ward off predation but do so in a way that also curtails innovation. Similarly, one can imagine institutional arrangements that encourage innovation, but do so in a way that permits predation, steering innovation toward activities that amount to citizens' efforts to "out predate” their compatriots. Neither of these institutional regimes is robust. ${ }^{9}$ They fail unless individuals are either altruistic, and thus don't reduce their socially beneficial entrepreneurial activities when the payoff of those activities falls, or angelic, and thus don't respond to opportunities for predation when those opportunities expand and become more lucrative. In contrast, national competitiveness requires politicaleconomic robustness - institutional regimes that function both when individuals respond to incentives for both productive and unproductive activity. The only way to determine which institutions are robust is to engage in comparative analysis over the feasible set of alternatives.

\section{Conclusion}

We conclude our analysis by highlighting several implications of the comparative historical political economy approach we've described as they relate to reform efforts interested improving national competitiveness in the developing world. First, comparative historical political economy emphasizes that economic behavior, organizations, and policies never exist in a vacuum but always within a broader social context. The importance of historically

8 Hayek (1978: 185) argued that "we do injustice to the achievement of the market if we judge it, as it were from above, by comparing it with some ideal standard which we have no known way of achieving.” Instead, Hayek argued, the market must always be judged from "below"-from what would be achieved if competition had in fact been prevented. A provocative claim in this essay of Hayek's is also that the scientific method is in a similar position as that of market competition and cannot be assessed against some idealized standard, but only against the relevant comparisons.

9 This relates again methodologically to the question of case selection and the "power" of the analysis provided. If social cooperation can be demonstrated to have emerged in situations where the initial conditions are unfavorable, then the institutional mechanisms in operation are robust. On the limits of spontaneous order explanations of social order see Hodgson (2009), however see Leeson and Boettke (2009) for how entrepreneurial action can be invoked over the rules of the economic game to improve it, just as entrepreneurial action is invoked within a given set of rules to realize the gains from trade and the gains from innovation. 
dependent institutional factors for national competitiveness seems obvious. Yet attempts by the international community to foster national competitiveness in underdeveloped countries seem not to recognize this fact or at least don't account for it in practice.

Second, comparative historical political economy highlights how history matters for a society's competitiveness. History influences institutional stickiness and constrains what institutional movements are possible in practice. The status quo that emerges from historical experience must be the starting point of any discussion of national competiveness.

Third, comparative historical political economy emphasizes that understanding national competitiveness is a matter of comparing relevant—and thus feasible-institutional alternatives. The purpose of reform is to improve nations' competitiveness in a sustainable way. Failing to get the benchmark right will lead to faulty reform conclusions, encouraging backsliding at best and reducing nations' competitiveness at worst.

\section{References}

Acemoglu, D., S. Johnson, and J. Robinson (2001), 'The Colonial Origins of Comparative Development: An Empirical Investigation’, American Economic Review, 91(5): 1369-1401.

Acemoglu, D., S. Johnson, and J. Robinson (2002), 'Reversal of Fortune: Geography and Institutions in the Making of the Modern World Income Distribution', Quarterly Journal of Economics, 117(4): 1231-1294.

Acemoglu, D. and J. Robinson (2012), Why Nations Fail, New York: Crown.

Bates, R. H., A. Grief, M. Levi, J. L. Rosenthal, and B. R. Weingast (1998), Analytic Narratives, Princeton: Princeton University Press.

Besley, T. and T. Persson (2011), Pillars of Prosperity: The Political Economics of Development Clusters, Princeton: Princeton University Press.

Boettke, P. J. (1990), The Political Economy of Soviet Socialism: The Formative Years, 19191928, Boston: Kluwer Academic Publishers.

Boettke, P. J. (1993), Why Perestroika Failed, New York: Routledge.

Boettke, P. J. (2002), Calculation and Coordination: Essays on Socialism and Transitional Political Economy, New York: Routledge.

Boettke, P. J. (2012), Living Economics: Yesterday, Today, Tomorrow, Guatemala City: Universidad Francisco Marroquin Press.

Boettke, P. J. and P. T. Leeson (2004), 'Liberalism, Socialism, and Robust Political Economy', Journal of Markets and Morality, 7: 99-12.

Boettke, P. J., C. J. Coyne, and P. T. Leeson (2008), 'Institutional Stickiness and the New Development Economics', American Journal of Economics and Sociology, 67(4): 331-358.

Boettke, P. J., C. J. Coyne, P. T. Leeson, and F. Sautet (2005), 'The New Comparative Political Economy’, Review of Austrian Economics, 18(3): 281-304.

Boettke, P. J. and V. Storr (2002), 'Post-Classical Political Economy: Polity, Society, and Economy in Weber, Mises and Hayek', American Journal of Economics and Sociology, 61: 161-191.

Boulding, K. (1948), 'Review of Paul Samuelson's Foundations of Economic Analysis', Journal of Political Economy, 56: 187-199. 
Buchanan, J. M. (1975), The Limits of Liberty, Chicago: University of Chicago Press.

Buchanan, J. M. and Y. Yoon (1994), The Return of Increasing Returns, Ann Arbor: University of Michigan Press.

Coyne, C. J. (2006), 'Reconstructing Weak and Failed States: Foreign Intervention and the Nirvana Fallacy', Foreign Policy Analysis, 2: 343-361.

Coyne, C. J. (2008), After War: The Political Economy of Exporting Democracy, Stanford: Stanford University Press.

Coyne, C. J. (2013), Doing Bad By Doing Good: Why Humanitarian Action Fails, Stanford: Stanford University Press.

Coyne, C. J. and P. T. Leeson (2009), 'Media as a Mechanism of Institutional Change and Reinforcement', Kyklos, 62: 1-14.

Denzau, A. and D. C. North (1994), 'Shared Mental Models: Ideologies and Institutions', Kyklos, 47: 3-31.

Djankov, S., E. Glaeser, R. La Porta, F. Lopez-de-Silanes, and A. Shleifer (2003), 'The New Comparative Economics', Journal of Comparative Economics, 31: 595-619.

Durlauf, S. N., P. A. Johnson, and J. Temple (2005), 'Growth Econometrics', in Philippe Aghion and Steven Durlauf (eds), Handbook of Economic Growth, Vol. 1A, Amsterdam: Elsevier, pp. 555-677.

Easterly, W. (2001), The Elusive Quest for Growth, Cambridge: MIT Press.

Easterly, W. (2006), White Man’s Burden, New York: Penguin Press.

Friedman, M. (1947), 'Lerner on the Economics of Control', Journal of Political Economy, 55: 405-16.

Greif, A. (2006), Institutions and the Path to the Modern Economy, Cambridge, UK: Cambridge University Press.

Hall, J. C., and P. T. Leeson (2007), 'Good for the Goose, Bad for the Gander: International Labor Standards and Comparative Development', Journal of Labor Research, 28: 658676.

Hayek, F. A. (1978), 'Competition as a Discovery Procedure', in F.A. Hayek (ed.), New Studies in Philosophy, Politics, Economics and the History of Ideas, Chicago: University of Chicago Press.

Hodgson, G. (1988), Economics and Institutions, Philadelphia, PA: University of Pennsylvania Press.

Hodgson, G. (1993), Economics and Evolution: Bringing Life Back Into Economics, Ann Arbor, MI: University of Michigan Press.

Hodgson, G. (1999), Evolution and Institutions: On Evolutionary Economics and the Evolution of Economics, Cheltenham, UK: Edward Elgar.

Hodgson, G. (2001), How Economics Forget History, New York: Routledge.

Hodgson, G. (2009), 'On the Institutional Foundations of Law: The Insufficiency of Custom and Private Ordering', Journal of Economic Issues, XLIII(1): 143-166.

Hodgson, G. (Forthcoming), Conceptualizing Capitalism: Essence, Institutions, Evolution, Mimeo, February 13.

Leeson, P. T. (2007a), 'An-arrgh-chy: The Law and Economics of Pirate Organization', Journal of Political Economy, 115: 1049-1094.

Leeson, P. T. (2007b), 'Trading with Bandits', Journal of Law and Economics, 50: 303-321.

Leeson, P. T. (2007c), 'Better Off Stateless: Somalia Before and After Government Collapse', Journal of Comparative Economics, 35: 689-710. 
Leeson, P. T. (2008), 'Social Distance and Self-Enforcing Exchange', Journal of Legal Studies, 37: 161-188.

Leeson, P. T. (2009a), 'The Laws of Lawlessness', Journal of Legal Studies, 38: 471-503.

Leeson, P. T. (2009b), 'The Calculus of Piratical Consent: The Myth of the Myth of Social Contract', Public Choice, 139: 443-459.

Leeson, P. T. and J. R. Subrick (2006), 'Robust Political Economy', Review of Austrian Economics, 19: 107-111.

Leeson, P. T. and P. J. Boettke (2009), 'Two-Tiered Entrepreneurship and Economic Development', International Review of Law and Economics, 29(3): 252-259.

Leeson, P. T. and C. R. Williamson (2009), 'Anarchy and Development: An Application of the Theory of Second Best', Law and Development Review, 2: 77-96.

Lerner, A. P. (1944), The Economics of Control, New York: Macmillan Co.

Mirowski, P. (1991), More Heat than Light, Cambridge, UK: Cambridge University Press.

North, D. C. (1990), Institutions, Institutional Change and Economic Performance, Cambridge, UK: Cambridge University Press.

North, D. C. (2005), Understanding the Process of Economic Change, Princeton: Princeton University Press.

Ostrom, E. (1990), Governing the Commons, New York: Cambridge University Press.

Ostrom, E. (2005), Understanding Institutional Diversity, Princeton: Princeton University Press.

Ostrom, E., et al. (2001), Aid, Incentives and Sustainability: An Institutional Analysis of Development Cooperation, Stockholm, SW: SIDA.

Pierson, P. (2000a), 'The Limits of Design: Explaining Institutional Origins and Change', Governance, 13: 475-499.

Pierson, P. (2000b), 'Returns, Path Dependence and the Study of Politics', American Political Science Review, 94: 251-267.

Powell, B. and D. Skarbek (2006), 'Sweatshops and Third World Living Standards: Are the Jobs Worth the Sweat?', Journal of Labor Research, 27: 263-274.

Powell, B., R. Ford, and A. Nowrasteh (2008), 'Somalia After State Collapse: Chaos or Improvement?', Journal of Economic Behavior and Organization, 67: 657670.

Samuelson, P. (1947), Foundations of Economic Analysis, Cambridge: Harvard University Press.

Smith, A. (1976), An Inquiry into the Nature and Causes of the Wealth of Nations, Chicago: University of Chicago Press.

Smith, V. L, (2003), 'Constructivist and Ecological Rationality in Economics', American Economic Review, 93: 465-508.

The World Bank (2008), The Political Economy of Policy Reform, Report No. - 44288-GLB. Available at: http://siteresources.worldbank.org/EXTSOCIALDEV/Resources/Political_Economy_of _Policy_Reform.pdf.

Williamson, C. R. (2010), 'Exploring the Failures of Foreign Aid: The Role of Incentives and Information', Review of Austrian Economics, 23: 17-33. 